Karadeniz Uluslararası Bilimsel Dergi

Volume: 41, Spring-2019, p. 167-188

ISSN: 1308-6200 DOI Number: 10.17498/kdeniz.476335

Research Article

Received: October 30, 2018

Accepted: February 22, 2019

This article was checked by iThenticate.

\title{
SÜRDÜRÜLEBİLİR KALKINMADA AKILLI KENTLER
}

\author{
SMART CITIES IN SUSTAINABLE DEVELOPMENT
}

УМНЫЕ ГОРОДА В УСТОЙЧИВОЕ РАЗВИТИЕ

Aslı ÖZTOPCU* - Ayşe SALMAN**

\section{Öz}

Dünya nüfusunun artışıyla birlikte, kırsal kesimden kentlere olan göç hareketliliği de artış göstermektedir. Nüfus artışı, kent yaşamında kısa vadede bireysel fayda sağlasa da su, elektrik gibi kıt kaynak kullanımının ve sağlık, eğitim gibi hizmetlerin aksamasına neden olmaktadır. Kentsel sorunların en aza indirilmesi için devlet ve yerel yönetimler gibi, kent planlama alanında çalışan tüm kurum ve bireyler, kent yaşamını kolaylaştırıcı alternatifler üretme çabasındadır. Bu alternatiflerden biri yoğun teknoloji gerektiren akıllı kent sistemi ve buna bağlı geliştirilebilecek diğer teknoloji donanımlarıdır.

Özellikle gelecek kaygısı, küresel ısınma, dünyayı yaşanabilir kılma ve bunun sürdürülebilir olması gibi düşüncelerden dolayı toplum, yeni fikir ve kalkınma politikalarına yönelmektedir. Bugünkü yaşamı zorlaştıran koşullar geleceği de tehdit etmektedir. Kişi başına enerji tüketiminin giderler içindeki artışı, verimli sistemlerin üretilmesini zorunlu hale getirmiştir. Akıllı kent ya da diğer ifadeyle zeki kent, dijital kent, teknolojik kentlerin amacı gelecek nesillere yaşanabilir bir kent yaşamı bırakabilmektir.

$\mathrm{Bu}$ çalışmanın amacı, akıllı kentlerin sürdürülebilir kalkınma açısından etkilerini araştırmaktır. Önce akıllı kent literatürü araştırılmış, daha sonra yüksek lisans öğrenci çalışmaları değerlendirilmiştir. Uluslararası öğrenci kongresinde yer alan bildiriler irdelenmiştir. Elde edilen sonuçların gelecek ihtiyaçların belirlenmesi ve projelerin katkılarının literatüre taşınması açısından ışık tutacağı düşünülmektedir.

Anahtar Kelimeler: Sürdürülebilir kalkınma, Akıllı kent, Akıllı bina, Teknoloji, Refah Jel Kodları: D60, Q11,Q12, O30

\footnotetext{
Abstract

With the increase in the world population, the migration from rural to urban areas also increases. Although population growth provides short-term individual benefits in urban life, scarce resources such as water and electricity and health and education services are disrupted. In order to minimize the urban problems, all institutions and individuals working in the field

* ORCID: 0000-0001-6419-2425 Dr. Öğr. Üyesi, Maltepe Üniversitesi, İstanbul, Turkey. aoztopcu@ gmail.com

** ORCID: 0000-0003-2649-3061 Dr. Öğr. Üyesi, Maltepe Üniversitesi, İstanbul, Turkey. aysesalmantr@gmail.com
} 
of urban planning, such as state and local governments are trying to create alternatives to facilitate urban life. One of these alternatives is the smart city systems that require intensive technology and the technology equipment developed for these systems.

Especially; due to the future worries, global warming, making the world livable and sustainable, the society is turning to new ideas and development policies. Conditions which make life difficult in present threaten the future living. The increase in energy consumption per capita has made it necessary to produce efficient systems. The aim of smart cities or in other words technological or intelligent cities, digital cities are to leave a livable city life to next generations.

The aim of this study is to research the effects of smart cities on sustainable development. First, the smart city literature was researched and then post graduate student studies were evaluated. The papers in the international student congress were discussed. It is thought that the results will shed light on the determination of future needs and the contribution of the projects to the literature.

Keywords: Sustainable development, Smart city, Smart building, Technology, Welfare

\begin{abstract}
Аннотация
Наряду с ростом населения в мире увеличивается миграция из сельских районов в города. Рост населения обеспечивает краткосрочную прибыл в городской жизни. Однако, вызывает перебой в водо и электроснабжением, в сфере здравоохранения и образования. С целью минимизированя городских проблем, перебоя в разных учреждеий, сотрудники по городскому устроиству, государственные и местные органы власти, пытаются создать альтернативы, способствующие нормализации городской жизни. Один из альтернативов в этой обдасти является система интенсивного технологического оборудования т.н. “умного города”.

Беспокойство людей о будущем, глобальное потепление, загрязнение окружающей среды и устойчивое развитие, вынуждает общество обращается к новым идеям и новой политике. Условия, усложняющие сегодняшную жизнь, угрожают будущему. Увеличение потреблений энергии на душу населения привело к необходимости производства эффективных систем. Интеллектуальные города, другим словом интеллигентные города, цифровые города, технологические города, стремятся оставить жизнь пригодным для будущего поколения.

Цель данного исследования изучить влияние умных городов на устойчивое развитие. С перва нами была исследована литература по поводу т.н. “умного города”, после чего оценивались исследования магистрантов. Были обсуждены доклады, представленные на международном студенческом конгрессе. Ожидается, что результаты исследования помогут определить потребности будущего и итоги проектов будут отражены в соотпетствующей литературе.
\end{abstract}

Ключевые слова: устойчивое развитие, умный город, интеллектуальное здание, технологии, процветание.

Гель коды: D60, Q11, Q12, O30 


\section{Giriş}

İnsanoğlunun bir arada yaşamak için kurduğu köy, kasaba, kent gibi yaşam alanları, yaşam döngüsü içinde sürekli değișmektedir. Bununla birlikte olumlu gelişmelere rağmen, dağınık yaşam alanları yerine özellikle kırsal alanlardan gelişmiş kentlere yönelen göç hareketliliği ve nüfus artışı, yaşam alanlarının yetersiz kalmasına neden olmaktadır.

1800'lerde dünya nüfusunun \%3‘ü, 2010'larda \%50'den fazlası kentlerde yaşarken, 2025'lerden itibaren \%70'den fazlasının kentlerde yaşayacağı öngörülmektedir (Ilıkcan, 2018). Bu bağlamda istatistiklere bakıldığında 1993-2007 yıllarında dünya nüfusunun sadece \%12'sinin metropollerde (en büyük kent) yaşamaktayken, yakın zamanda bu oranın da sürekli arttığı gözlenmektedir. Kentlerdeki nüfus artışıyla birlikte kalkınma düzeyi belirleyicilerinden GSMH (Gayri Safi Milli Hâsıla) düzeyinde de benzer bir artış görülmektedir. Geçmiş yıllarda dünyadaki en büyük iki yüz metropol yaşamının GSMH'ya katkısı \%46 iken, 2010'dan sonra oranda da sürekli artış olduğu gözlenmektedir (Istrate, Berube \& Nadeau, 2011). Ancak, kent yaşamının tercih edilmesi ülke ekonomik düzeylerinde artış sağlarken, refah ve yaşam standartları açısından karmaşık bir duruma dönüşmektedir. Kent yaşamı, insan yaşamını kolaylaştırmakta ve birey gelişimine birçok imkan sunmakta gibi görünürken, eşitsizliğin yoğun yaşandığ karmaşıklık ve kaos da beraberinde gelmektedir.

Eğer kent yaşamında düzgün bir kent yönetimi yoksa tercih edilme amacının aksine olumsuz yaşam ortamına neden olabilmektedir (Monzon, 2015: 17). Bu bağlamda, sürdürülebilir kalkınma perspektifinden kent yaşam biçimlerinin ele alınması önemli çözüm alternatiflerinden biri olmaktadır. Çünkü, ısınma ve elektrik ihtiyacını karşılayan kömür, petrol gibi çevre kirliliğini artırıcı kaynaklar yaşamı olumsuz etkilemekte (Varınca \& Gönüllü), enerji fiyatlarındaki artış, küresel ısınma, enerji kaynaklarının azalması gibi olaylar, gelecek nesillerin yaşamını tehdit etmektedir.

Sürdürülebilir kalkınma kavramının temelinde ise gelecek kuşakların ihtiyaçlarını karşılayabilme imkânı için bugünkü dünyanın ihtiyaçlarını karşılamaya odaklı bir kalkınma bulunmaktadır. Özellikle Uluslararası Doğayı ve Doğal Kaynakları Koruma Birliği (1980)'nin hazırladığı Dünya Koruma Stratejisi (World Conservation Strategy) raporu sonrasında sürdürülebilir kalkınma araştırmalarının önemi ortaya konmuştur. Çünkü sürdürülebilir kalkınma, sosyal, ekonomik ve çevresel alanda ilişki ve denge kurmayı hedeflemektedir (Seydioğulları, 2013: 19).

Kalkınma temelindeki insan refahının sürdürülebilir olması için ise, tasarrufların artırılmasıyla birlikte verimlilikte de artış gerekmektedir. Bu bağlamda kısıtlı kaynaklarla, sürekli gelişen teknoloji işbirliğinin kalkınmadaki etkisi önemlidir. Örneğin, Rio Dünya Zirvesinde (Haziran 1992) Birleşmiş Milletler Çevre ve Kalkınma Konferansı Gündem 21; kalkınma ve ekolojik çevre arasında denge kurulmasının önemi ve bunun nasıl yapılacağ üzerinde durmaktadır. Bu bağlamda yapılan anlaşmalardan birinde iklim değişikliklerine karşı protokol imzaya açılarak atmosferdeki sera gazının, iklim sistemi üzerindeki insana etkisinin azaltılması amaçlanmıştır. Bu ve benzeri çalışmalar, yaşamı kısıtlayan unsurlar nedeniyle, yaşamı kısıtlamayan yenilebilir enerji kaynakları gibi alternatiflere yönelme zorunluluğundan ortaya çıkmaktadır. $\mathrm{Bu}$ şekilde hem insanlığın temel ihtiyaçları karşılanacak, hem refah düzeyinde artış sağlanacak hem de ekosistemin korunması mümkün olacaktır.

Japonya'da COP3 (3. Taraflar Konferansı)'te (Aralık 1997) dünya çapında sera gazlarının azaltılması için bağlayıcı hedefler içeren "Birleşmiş Milletler İklim Değişikliği Çerçeve Sözleşmesi’ne Illişkin Kyoto Protokolü” imzalanmıştır. Son olarak Fransa'da düzenlenen 21. Taraflar Konferansı'nda (Aralık 2015), Paris anlaşması, 2020'de devreye 
girecek yeni bir anlaşma olarak imzalanmıştır. 2017 itibariyle de 197 taraf ülke Paris anlaşmasını onaylanarak küresel boyutta bir işbirliği gerçekleştirmiştir (Enerji ve Tabi Kaynaklar Bakanlığı Bilgi Merkezi, 2018). Taraftar konferansı, günümüz enerji tüketimindeki israfı azaltmak, sürdürülebilir enerji üretimine yönelmek ve verimli olmak ilkeleri doğrultusunda gerçekleştirilmektedir. Bu amaçla, az enerji tüketimi adına tamamen yalıtılmış ve kapatılmış binalar yerine, atmosferle alışveriş yapan yapılar tasarlanması ve bunun sürdürülebilir olmasına önem verilmektedir. Bugünkü teknoloji yapısıyla, elektrik, su ve gaz gibi kullanımlarda sarfiyatı önleyici ve kendini kontrol edebilen sistemler kurulabilmektedir.

Enerji tüketiminin en büyük nedenlerinden biri konut tipi binalardaki sarfiyattır (Anbarc1, Giran \& Demir, 2012: 369). Klasik yöntemlerle yapılan binalarda kullanılan enerjilerin verdiği zararlar; küresel ısınma, stratosferdeki ozon delinmesi, asit yağmurları, su ötrofikasyonu

${ }^{1}$, doğal hayatta değişim, ekolojik zehirlilik gibi yaşam açısından tehdit edici ekolojik yıkımlardır. Ayrıca, hava kirliliği, sağlığı bozan madde yayılımı, kansorejenler gibi oluşumlar insan sağlığını tahrip eden olumsuzluklardır. Fosil yakıtlar, temiz su, mineraller ve üst toprak değişimleri ise kaynak tüketimini etkileyen olumsuzluklardır (Özçuhadar \& Öncel, 2017: 7). Bu olumsuzlukların azaltılabilmesi için kentsel alanların gelişmeye yöneltilmesi, ekonomik rekabetçiliği desteklemesi ve gelecek nesillere taşınabilir biçimde tasarlanması önemlidir.

Sözü geçen olumsuzlukların ve insan yaşamını tehdit eden unsurların en aza indirgenmesi için multi disipliner çalışmalara ihtiyaç duyulmaktadır. Akıllı binaların (yeşil bina) bulunduğu akıllı kentlere geçiş, bu alternatiflerden biridir. Bu alandaki çalışmalar, akıllı kentlerin gelecek yaşam alanları için önemli olduğunu göstermektedir. Amerika'da yapılan bir araştırmada yeşil binaların, enerji tüketiminde \%24-50 arasında, CO2 salınımında \%3339 arasında, su tüketiminde $\% 40$ civarında ve atıklarda $\% 70$ civarında azalma sağlayacak etkide olduğu tespit edilmiştir (Yeşil Derneği; 2016) .

Akıllı kavramı genel anlamda; enformasyon teknolojileriyle, denetleme sistemlerinin birbiriyle ilişkilendirilmesi ve maliyet azaltıcı, verimlilik artı̧ı sağlayan sistemler için kullanılmaktadır (Civan, 2006: 12). Akıllı sistemler; 1sıtma, soğutma, aydınlatma, yangın ve güvenlikte maksimum etkinlik sağlayan merkezi sistemlerdir. Akıllı binalar için tasarlanan sistemler, sözü geçen konuları etkin biçimde gerçekleştirebilmek için bilgisayar sistemleriyle yönetilebilen birçok teknolojik sistemi bir arada kullanabilme becerisini gösteren sistemlerdir. Literatürdeki araştırmalarda sürdürülebilir ve akıllı kentler kavramı genellikle birbiriyle aynı anlamları taşımaktadır. Dolayısıyla İnşa edilen binalar ve alt yapı sistemleri için, binaların içinde ve dışında çevresel sorunlara doğrudan ve dolaylı katkıda bulunmakta olan sürdürülebilir sistemlerdir demek mümkündür.

Akıllı kentler (smart city), kendi içinde akıllı binalar, akıllı yerleşim alanı ya da iş merkezleri gibi alt parçaları kapsayan bir yapılanmadır (Greenbang, 2012). Öncelikle akıllı binaları ifade eden sistemlerin, özellikle yeni yerleşim alanları ya da kentleşme, dönüşüm projeleri bazında daha geniş formlarda değerlendirildiği anlaşılmaktadır. Akıllı binalardan akıllı kentlere geçiş ise bu sürecin çıktısını oluşturmaktadır. Diğer bir ifadeyle akıllı kentlerin nihai hedefi, kent yönetimine yeni bir yaklaşım getirmektir.

\footnotetext{
${ }^{1}$ Ötrofikasyon: Büyük su ekosistemlerinde farklı nedenlerle besin maddelerinin çoğalması ekosistemde plankton ve alglerin oluşumuna neden olmaktadır. Sözü geçen maddeler sudaki oksijeni tükettiği için uzun vade de ekosistemin ölmesine neden olabilmektedir.
} 
Akıllı kent kavramı, büyümenin çeşitli sosyoteknik ve sosyoekonomik yönlerini ele alan belirli bir entelektüel yetenek olarak tanımlanabilir. Akıllı kentler bu bağlamda yeşil, geniş bant (ağ ve şebeke) ekonomisi, ve birbirine bağlı yenilikçi, akıllı inovasyon ekosistem özellikleridir. $\mathrm{Bu}$ özellikler, akıllı kent anlayışına, çevre koruma ve CO2 emisyonunun azaltılması gibi amaçlar için kentsel altyapıya atıfta bulunmaktadır. (Zygiaris, 2013). Bu bağlamda akıllı kent girişimleri, kent yaşamına daha verimli hizmetler sunmak, mevcut altyapıyı izlemek ve optimize etmek, farklı ekonomik aktörler arasında işbirliği yapmak ve yenilikçi iş modellerini teşvik etmek için veri, bilgi ve bilgi teknolojilerini (BT) kullanarak kentsel performansı artırmaya çalışmaktadır (Marsal-Llacuna; Colomer-Llinàs \& MendelesFrigola, 2014). Bu bağlamda sürdürülebilir kalkınma yaklaşımında akıllı teknolojilerden yararlanmanın önemi büyüktür. Bilgi teknolojisi ve kontrol sistemlerinin birlikte ele alınmasıyla tasarlanan akıllı yöntemler, binaların işlevselliğini artırmak için kullanılır. Buradaki odak nokta, sistemin sürdürülebilirliğinin nasıl sağlanacağıdır. Çünkü temel amaç, çevresel sürdürülebilirlikten daha çok ekonomik ve sosyal sürdürülebilirliktir (Bell, 2003).

Akıllı sistemler, ilk başlarda hangi açıdan ihtiyaç duyulduysa sadece ona hizmet etmekteydi. Ancak sistemlerin birbirinden bağımsız olması, akıllı binanın bir bütün olarak değerlendirilmesini mümkün kılmıyor ve karmaşıklığa sebep oluyordu. Daha sonra bu sistemlerin bir ağ ile birbirlerine bağlanması ve bir merkezden yönetilebiliyor hale getirilmesi mümkün oldu. Bu aşama itibariyle akıllı binalar ya da sistemler diyebileceğimiz gerçek bir ağ sistemi başlatılmış oldu. Son olarak bu sistemlerin genişletilmesi, kendini kontrol edebilmesi ve karmaşı sistemlerin daha kolay müdahale edilebilir hale getirilmesiyle şu anki sistemler kurulmaya başladı (Sharples, Callaghan \& Clarke, 1999). Gelecekte bunların daha geliştirilebilir olacağı söylenmektedir. Hayallerle ihtiyaçların motivasyonu, bugün öngörülmesi zor olan yeni ya da inovatif yaklaşımların gerçekleşmesini sağlamaktadır.

Eger (2009)'e göre akıllı kentler, akıllı toplumların yaşam alanlarıdır. Akıllı toplumlar; yüksek hızlı genişbant altyapılarını inşa etmeye odaklanacak, ancak bulundukları yerin duygusunu da yeniden inşa etmek ve yenilemek isteyeceklerdir. Akıllı topluluklar; özünde, teknolojinin koşullandırmasında ve kullanılmasında değil, ekonomik kalkınmanın, iş büyümesinin ve artan yaşam kalitesinin teşvik edilmesiyle hareket etmektedirler. Başka bir deyişle, akıllı toplulukların teknolojik yayılımı, kendi başına bir amaç değil, yalnızca kentleri yeni bir ekonomi ve toplum için açık ve zorlayıcı bir toplum yararı ile yeniden yaratmanın araçlarındandır (Eger, 2009).

Bu bağlamda akıllı kent uygulamaları, multi disiplininer işbirliği gerektirmektedir. Önce hedef alınan alan, mahalle ya da şehre ait bir projelendirmeye ihtiyaç duyulur. Proje ölçeği ve gelişme oranı belirlenerek finansal bütçe ve kaynakların tespiti yapılarak süreç başlatılır. Uzun süreli ve sürekli iyileştirme ile gerçekleştirilecek projeler sonucunda ise akıllı kentler, diğer ifadeyle öğrenen kentler; insan yaşamına, ekosistemlere ve kalkınmaya sürekli pozitif etki sağlayacaktır.

Eğitime dayalı olarak akıllı bir kent, yükseköğretim, daha iyi eğitimli bireyler ve vasıflı iş gücü merkeziyle donanacaktır. Akıllı kentler, yaratıcı insanlar ve işçiler için mıknatıs görevi gördüğünden, onları daha akıllı ve daha akıllı hale getiren erdemli bir çevrenin yaratılmasına olanak tanımaktadır. Dolayısıyla, akıllı bir kent, insan potansiyelini ortaya çıkarmak ve yaratıcı bir yaşamı teşvik etmek için birçok firsata da sahiptir (Winters, 2011). Kısaca, eğitimli işgücünün yüksek olduğu kentlerde en hızlı kentsel büyümenin elde edileceğini söylemek mümkündür. (Dirks, Gurdgiev \& Keeling; 2010).

Bugünkü anlayıșta akıllı kent ve akıllı kent sistemlerinin bileşenlerini akıllı insan, akıllı yaşam, akıllı yönetişim, akıllı ulaşım, akıllı çevre ve akıllı ekonomi olarak ifade etmek 
mümkündür (Cohen, 2013). Bu bağlamda küresel boyutta çalışmaların bu bileşenlerin hepsini içerdiğini ya da bir kaçının temel alınarak yapıldığını görmekteyiz.

Görüldüğü gibi, sürdürülebilir yaşam alanlarının en önemli unsurlarından biri kent yaşamıdır. İnsan yaşamının rahat ve konforlu sürdürülebilmesi için birçok yeni ve özellikli yapılandırmaya ihtiyaç vardır. Bunlardan biri de akıllı kentlerdir. Bu çalışmanın amacı, akıllı kentlerin, kalkınma ve insan yaşam kalitesi açısından değerlendirilmesi ve gelecek yaşam alanlarının nelere ihtiyaç duyacağını ortaya koymaktır. Bu amaçla öncelikle akıllı kentlerle ilgili literatür gözden geçirilmiş daha sonra yüksek öğrenimde bu akıllı kent çalışmalarında hangi konularda eğilim olduğu tespit edilmeye çalışılmıştır. Bu çalışmaların çok sayıda olması nedeniyle konuyla ilgili uluslararası öğrenci kongresinde tebliğ edilen çalışmalar üzerinden değerlendirme yapılmasının uygun olacağı düşünülmüştür.

\section{Akıllı Kentler}

Akıllı kent kavramını anlamak için, kentlerin neden gelecek için önemli olduğunu da anlamak gerekir. Kentler, dünya çapında sosyal ve ekonomik açıdan önemli bir rol oynamaktadır ve çevre üzerinde büyük bir etkiye sahiptir (Mori and Christodoulou, 2012). $\mathrm{Bu}$ nedenle akıllı kent kavramıla ilk akla gelen unsur, akıllı binalar ve akıllı sistemler olmaktadır. Bu sistemlerin işleyişi aynı zamanda bir şehrin temel yapıtaşı olan binaları, alt yapısını, trafik ve işleyişini kapsamaktadır. Bazen belirli yer ve alanlar için ihtiyaçlar doğrultusunda akıllı alanlar tasarlanırken bazen de kentsel dönüşüm projeleri için tasarımlar yapılmaktadır. Dünyada onlarca örneği bulunan bu sistemlerin (Los Angeles; MetronetMalezya; Multimedya Süper Koridoru, Telecities projesi, ODTÜ Teknokent vd.) irdelenmesi için öncelikle akıllı bina kavramını değerlendirmek daha doğru olacaktır.

\subsection{Akıllı Bina}

Akıllı kavramından sonra tanımlanması gereken ikinci kavram akıllı bina kavramıdır. 1980'lerden beri kullanılmaya başlanan akıllı bina; EIBG'ye (European Intelligent Building Group) göre, bina sakinlerinin verimliliğini artıran bir ortam oluştururken, kaynakların en düşük maliyetle sonsuz kullanımı için verimli yönetimin sağlanmasıdır (Serbini \& Krawczyk, 2004). Diğer bir ifadeyle IBI'ya (U.S Intelligent Building Institute) göre akıllı bina; sistem, yap1, servis ve yönetim elemanlarının optimizasyonu ve aralarında ilişki kurarak maliyet verimli ortam elde edilmesidir (Peluffo, 2015). Network sistemiyle entegre edilen sistemler, bileşenleri bağlayan bir "fiziksel" bağlantı kurularak ya da kablolu bağlantı veya radyo sinyaliyle (kablosuz durumunda olduğu gibi) ilişkilendirilmektedir. Bunların dışında çeşitli bileşenlerin birbirleriyle iletişim kurabildikleri ve bir "iletişim protokolü" aracılığıyla bilgi alışverişi yapabilecekleri ortak bir dil sistemiyle de entegre edilebilmektedir. Sözü geçen iletişim protokülünde sıklıkla kullanılan protokoller UPnP (Evrensel Tak ve Çalıştır), BACnet (Bina Otomasyon ve Kontrol Ağı) ve DLNA (Dijital Yaşam Ağı İttifakı)'dır.

Akıllı binalarla ilgili ilk çalışma Markus modelidir. Markus (1967) tarafından yapılan bina tasarımında daha önceki yapılardan farklı özellikler bulunmaktadır. İnşaat, hizmet, fiziksel ve görsel yapılandırmayı içeren tasarımda; çevre sistemi ve kullanıcı aktivite sistemi arasında arayüz kurulmuştur (Clements, 1998; Ofoegbu \& Ogunmakinde, 2014). Bununla birlikte Markus'a ait bina ilk onaylanan akıllı bina değildir. Kayıtlarda yer alan ilk akıllı bina ABD'de (1981) UTBS Corporation (United Technology Building Systems Corporation) tarafından yapılan Connecticut Hartford'da açılışı yapılan "City Place" (1983) diye adlandırılan binadır. UTBS Corporation bu projede, klima ekipmanı, asansörler ve felaketleri önleme cihazları gibi ekipmanların kontrol edilmesinden ve çalıştırılmasından 
sorumlu olmakla birlikte, her kiracıya ofis otomasyon hizmetleri, yerel alan ağları (LAN), dijital özel otomatik şube santralleri (PABX) ve bilgisayarlar gibi iletişim destek hizmetleri vermiştir. Tanımlardan da anlaşılacağı gibi akıllı binaların özellikleri oldukça fazladır. $\mathrm{Bu}$ özellikler ve bu amaçla üzerinde çalışılan konular aşağıdaki gibi gösterilebilir:

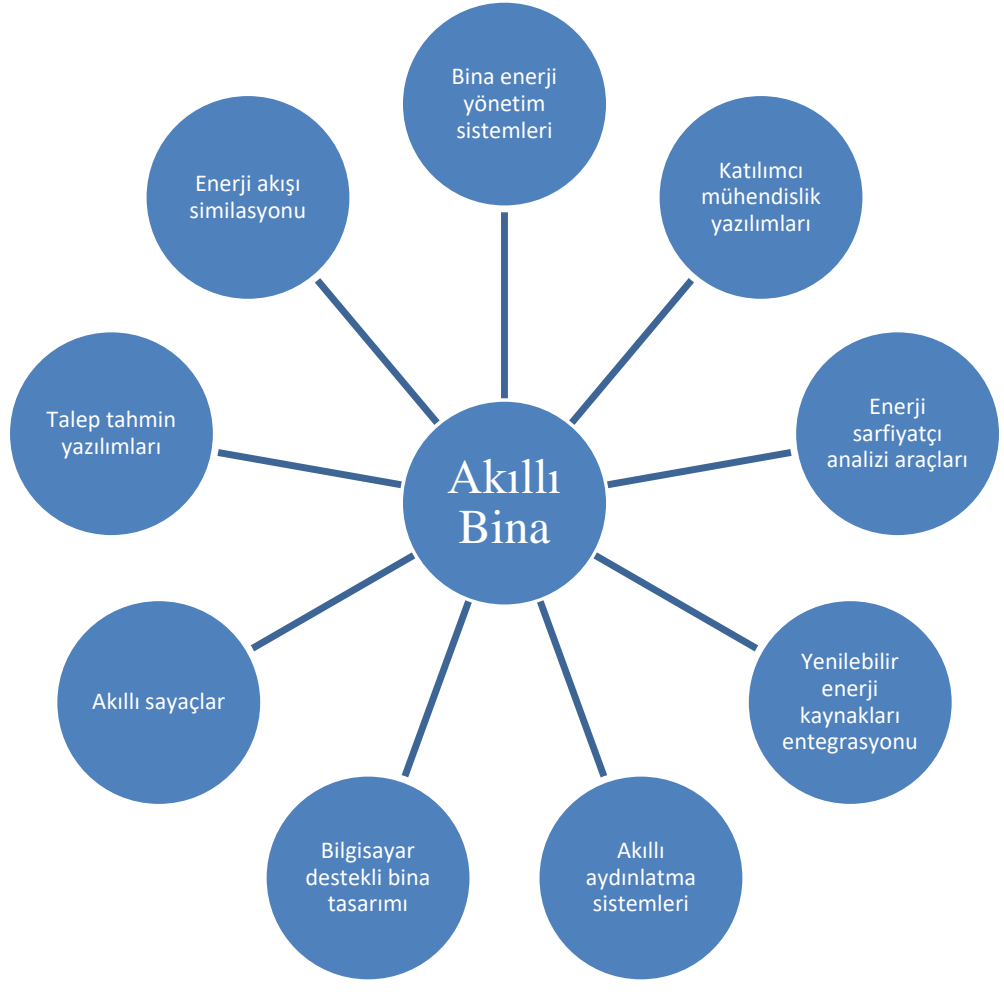

Şekil 1. Akıllı Bina Sitemlerinin Temel İşlevleri

Kaynak: Karagöl, B. (2013). Bilgi ve İletişim Teknolojilerinin Enerji

Verimliliğine Katkısı. Yayınlanmış Uzmanlık Tezi. Bilgi Toplumu Dairesi Başkanlığı. Yayın no: 2850, 38.

Tüm icatlarda olduğu gibi akıllı yapılarda da, kıt kaynaklar ve nüfus artışıyla birlikte değişen ihtiyaçlar doğrultusunda binalar projelendirilmektedir. İhtiyaç duyulan alanlarda sözü geçen konularla (şekill.) ilgili oluşturulan bilişim tabanlı sistemlerin, belirli standartlarda olması ise bu projelerin sürdürülebilirliği ve yüksek kalitede olması açısından önemlidir. Diğer bir açıdan da sürdürülebilirlik hedefi olan çalışmalarda somut araçlar kullanılması gerekliliğidir. Bu araçlar, standartlar, sertifikalar ve bunlara bağlı geliştirilen stratejilerdir (Özçuhadar \& Öncel, 2017: 9).

Yaşama zarar veren ve geleceği tehdit eden konular STK'larını (sivil toplum kuruluşları) harekete geçirmiştir. Dünya liderleri arasında yapılan işbirlikleri sonucunda Kyoto Protokolü (1997), Stokholm Sözleşmesi (2000), Montreal Protokolü (1987) gibi anlaşmalar yapılmıştır. Bu duyarlılığın giderek artması sonucunda yapı sektöründe yeşil bina olarak adlandırılan ekolojik binalar ortaya çıkmıştır (Erdede, Erdede \&Bektaş, 2014). Bu 
bağlamda geliştirilen metotlar; bina standartları, ürün sertifikaları, değerlendirme sistemleri ve tasarım araçları gibi başlıklar altında toplanmaktadır. Özellikle 1990 sonrasında ülkeler, ölçütlere dayalı değerlendirme ve sertifika metotları geliştirerek kontrol edilebilir sistemler üretilmesini sağlamışlardır. Ölçeğe dayalı değerlendirme, literatür kapsamında sertifikasyonlar ve hangi ülkelerde oluşturulduğu aşağıdaki gibi ifade edilebilir:

Tablo1. Ölçütlere dayalı değerlendirme ve sertifika metotları

\begin{tabular}{|c|c|c|c|}
\hline Yılı & Ülke & Adı & Açık Adı \\
\hline 1990 & İngiltere & BREEAM & $\begin{array}{l}\text { Bina Araştırma Kurumu Çevresel Değerlendirme } \\
\text { Metodu }\end{array}$ \\
\hline 1993 & Kanada & BEPAC & $\begin{array}{l}\text { Çevresel Performans Değerlendirmesi Oluşturma } \\
\text { Kriterler }\end{array}$ \\
\hline 1996 & Hong Kong & HK- BEAM & Binalarda Çevresel Etki Değerlendirme Metodu \\
\hline 1998 & $\mathrm{ABD}$ & LEED & Enerji ve Çevresel Tasarımda Liderlik \\
\hline 1999 & Tayvan & EEWH & Ekoloji, Enerji Korunumu, Atık Azaltımı ve Sağlık \\
\hline 2000 & Kanada & Green Globes & Yeşil Dünya \\
\hline \multirow[t]{3}{*}{2002} & $\begin{array}{l}\text { Güney } \\
\text { Kore }\end{array}$ & GBCS & Yeşil Bina Sertifika Sistemi \\
\hline & Avustralya & Green Star & Yeşil Yıldız \\
\hline & Çok Uluslu & SB-Tool & Sürdürülebilir Bina Aracı \\
\hline 2003 & İtalya & $\begin{array}{l}\text { Protocollo } \\
\text { Itaca }\end{array}$ & Itaca Protokolü \\
\hline \multirow[t]{2}{*}{2004} & Japonya & CASBEE & $\begin{array}{l}\text { Yapılı Çevrenin Etkinliğine Yönelik Kapsamlı } \\
\text { Değerlendirme Sistemi }\end{array}$ \\
\hline & Norveç & Eco Profile & Eko Profil \\
\hline \multirow[t]{5}{*}{2005} & Singapur & Green Mark & Yeşil İşaret \\
\hline & İsrail & $\begin{array}{l}\text { Green } \\
\text { Building } \\
\text { Standard }\end{array}$ & Yeşil Bina Standardı SI-5281 \\
\hline & Portekiz & LiderA & $\begin{array}{l}\text { Sürdürülebilir inşaatın değerlendirilmesi için } \\
\text { gönüllü sistem }\end{array}$ \\
\hline & Fransa & HQE & Yüksek Çevre Kalitesi \\
\hline & Avustralya & Nabers & Ulusal AvustralyaYapılı Çevre Sınıflama Sistemi \\
\hline \multirow[t]{4}{*}{2006} & Çin & 3- Star & 3-Y1ld1z \\
\hline & Hindistan & GRIHA & $\begin{array}{l}\text { Entegre Habitat Değerlendirmesi için Yeşil } \\
\text { Derecelendirme }\end{array}$ \\
\hline & Finlandiya & PromisE & Binalar için Fin çevre değerlendirme aracı \\
\hline & Hong Kong & CEPAS & $\begin{array}{l}\text { Kapsamlı Çevresel } \\
\text { Değerlendirme şeması }\end{array}$ \\
\hline 2007 & Brezilya & $\begin{array}{ll}\text { GBC } & \text { Brasil } \\
\text { CASA } & \\
\end{array}$ & Yeşil bina Konseyi Endeksi \\
\hline \multirow[t]{2}{*}{2008} & İsviçre & Minergie & İsviçre Sürdürülebilir Bina Standard 1 \\
\hline & Almanya & DGNB & 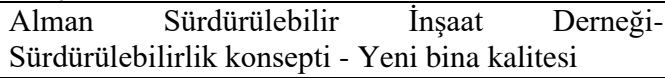 \\
\hline \multirow[t]{3}{*}{2009} & Malezya & GBI Malaysia & Yeşil Bina Endeksi \\
\hline & Filipinler & BERDE & $\begin{array}{l}\text { Ekolojik Duyarlı Tasarım Mükemmelliği } \\
\text { Derecelendirme Sistemi. PHILGBC (Filipin Yeşil } \\
\text { Bina Konseyi) }\end{array}$ \\
\hline & Endonezya & GBC & Yeşil Bina Konseyi Greenship sertifikası \\
\hline
\end{tabular}




\begin{tabular}{llll}
\hline Yılı & Ülke & Adı & Açık Adı \\
\hline 2010 & Birleşik & Pearl/ & Estidama (sürdürülebilirlik)için İnci Derecelendirme \\
& Arap & Estidama & Sistemi \\
& Emirlikleri & & \\
\hline
\end{tabular}

Kaynak: Farklı çalışmalar, sertifikasyon siteleri araştırılarak hazırlanmıştır.

Tüm sertifikasyon (Tablo1, vd.) ölçütleri, proje amaçlarına ulaşmayı kolaylaştırmakta ve sosyoekonomik sürdürülebilirlik açısından önemli bir ilerleme sağlamaktadır. Akıllı binalarda en çok kullanılan (Tablo1) ve aslında ilk akıllı bina kriterleri olarak kabul edilen Breeam ve Leed sertifikalarıdır. Breeam ve Leed bir süre sonra tüm dünyada yaygınlaşmaya başlamış ve bu yolla birçok ülkede enerji verimliliği ve sürdürülebilirliğe erişimi kolaylaşmıştır.

Breeam (The Building Research Establishment's Environmental Assessment Method) sertifika sistemi, ilk olarak BRE (Building Research Establishment) tarafından İngiltere (1990) de geliştirilmiştir. Dünya genelinde Breeam sertifikası 77 ülkede kullanılmaktadır. Sertifika kritelerinde iç mekan sağlık ve refahı, ulaşım, atık, bina yönetimi, enerji, su, ekoloji ile çevre konuları, malzeme ve arazi kullanımı gibi konular bulunmaktadır (Saunders, 2008). Breeam tarafından şu ana kadar yaklaşık 566 bin sertifika verilmiş ve 2 milyon 275 bin bina için başvuru alınmıştır (Breeam, 2018).

Leed (Leadership in Energy and Environmental Design) sertifika sistemi ise Amerikan Yeşil Binalar Konseyi tarafından oluşturulmuş yeşil bina sertifikasıdır. Bu sertifika mevcut tüm binalarda ya da inşaat halindeki binalarda kullanılabilmektedir. Dünya genelinde breeam sertifikası 164 ülkede kullanılmaktadır Puan tabanlı sistemde puan dağılımına göre enerji verimliliği ve karbon salınımını azaltacak kriteler belirlenir. Çevresel etki yaratan 13 unsur üzerinden değerlendirme yapılmaktadır. Bugün 94 bin projede Leed sertifikası bulunmaktadır.

Öncelikle Breeam ve Leed olmak üzere DGNB (Almanya), IISBE (Kanada), Greenstar (Avustralya), Casbee (Japonya) gibi sözü geçen tüm sertifika kriterlerinin temel amacı yönetim, sağlık, atık, su, arazi kullanımı, ekoloji, inovasyon, enerji ve ulaşım insan yaşamına etki eden kriterler değerlendirilmektir. Sözü geçen konular insanlığın ihtiyacı olma noktasındadır. Gelecekte ise çözülmesi gereken başlıca konular arasında olacaktır. $\mathrm{Bu}$ nedenle ülkelerin gelişmişlik düzeyindeki artış, alternatif çözümler için de etkili olmaktadır. Ülkelerin gelişmişlik düzeyi ile enerji verimliliği arasındaki ilişki önemlidir. Dünya nüfusundaki artışla birlikte kişi başına tüketilen enerji giderek artmaktadır. Aydınlatma ya da elektrikli ev aletleri gibi cihaz kullanımlarıyla harcanan enerji miktarının payı, toplam tüketim içinde sürekli artış göstermektedir (Kuhn \& diğ., 2011: 47-49.). Akıllı sistemlerin temel amacı ise, enerji tasarrufu sağlamaktır. Binalar ve sistemler için kriterleri belirleyen sertifikalar bu bağlamda en önemli rehberlik araçlarıdır.

\subsubsection{Akıllı Binaların Fonksiyonları}

Akıllı binalar aslında tasarlandıkları teknoloji ve uygulanma biçimlerinden dolayı akıllı olarak nitelendirilmektedir. Bu bağlamda sistemlerin fonksiyonları da tasarım amaçlarıyla aynıdır. Sertifika kriterlerinin de temel kapsamını oluşturan özellikler, bina sakinlerine en az maliyet verimliliği sağlamak için geliştirilmektedir. Akıllı bina sistemlerindeki fonksiyonlar, insan yaşamını kolaylaştıran, refah düzeyini artıran hizmetler sunmaktadır (Şekil 2.). 


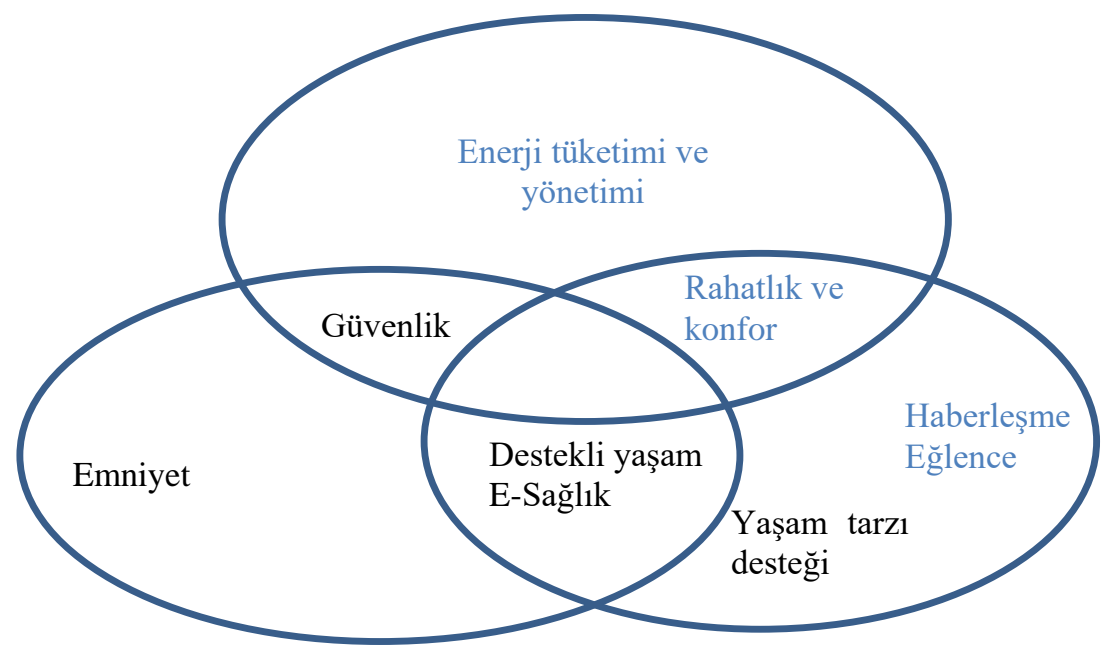

Şekil 2. Akıllı bina fonksiyonlarının hizmetleri

Kaynak: Zsebik, A. (2018). Smart/Intelligent Buildings. NOGATE Programme New ITS Project, Ad Hoc Expert Facility

Enerji etkin akıllı binalarda, enerji verimliliğini artırmak binanın diğer fonksiyonlarını da etkilemektedir. Örneğin akıllı kabuk olarak nitelendirilen sistem, dış ortamdaki durumlara göre binanın 1şık, iklim ve hava kalitesini ayarlayabilmektedir. Akıllı kabuk, doğal havalandırma, güneş kontrolü ve aydınlatma enerjisi maliyetlerini en aza indirmekte ve bina sakinlerine de konfor sağlamaktadır. Bu özelliklerin olmasını sağlayan ve gelecek nesillere de (sürdürülebilirlik) aktarılabilmesi için sertifikasyon kriterlerinde de değerlendirmeye alınan fonksiyonlar aşağıdaki gibidir:

Sağllk: Küresel sorunlardan biri olan sağlık sorunları, insan yaşamının uzantısıdır. Standart bina yapılarındaki birçok faktör insan sağlığını tehdit etmektedir. Akıllı binalar zamanının büyük çoğunluğunu bina içinde geçiren insanların yaşam kalitesini artırmaya çalışmaktadır. Isıtma, soğutma, gün ışı̆̆ından yararlanma, gürültü, akustik gibi sağlık faktörleri üzerinde etkili olan özelliklerin iyileştirilmesi amaçlanmıştır. Sözü geçen konularda alınan tedbirler hem fiziksel hem de psikolojik açıdan insan yaşamında olumlu etkiler oluşturmaktadır.

Güvenlik: Akıllı yönetim sistemleri, binalardaki güvenlik sistemleri olan yangın, su baskını, hırsızlık, gaz sızıntısı gibi olumsuzlukların saptanması, çözümlenmesi ve en aza indirgenmesi gibi etkilere sahiptir. Bununla birlikte itfaiye, polis, ambulans gibi yerlere otomatik bilgi vermekte, tesisatların bağlantısını keserek daha büyük kazaların olmasını engellemektedir. Ayrıca bu süreçlerde gereksiz enerji tüketimi de engellenmiş olmaktadır (Karagöl, 2013: 39). Yaşam kalitesini artırmakla birlikte insan yaşamını etkileyen maddi manevi unsurlar üzerinde de olumlu etkiler oluşturmakta ve oluşabilecek teknik hataları önlemektedir.

Enerji: Buradaki enerji kavramı oldukça geniş bir kapsamda değerlendirilebilir. Yenilebilir enerjiden tasarruf, enerji kaynaklarından teknoloji destekli uygulamalarla faydalanma gibi farklı amaçları bulunmaktadır. Ayrıca binadaki diğer sistemlerle entegre çalışması, sistem verimliliğine de imkân sunmaktadır. Örneğin, düşük enerjili aletlerle, $\mathrm{CO}_{2}$ salınımı, enerji etkin bina sistemleri ve enerji tasarruflu elektrikli-elektriksiz donanımlar 
üzerinde çalışmalar yapılmaktadır. USGBC (Amerikan Yeşil Binalar Derneği) ABD'de üretilen toplam enerjinin \%39'unu ve yalnızca elektrik enerjisinin \%74'ünü binaların tükettiğini tespit etmiştir. $\mathrm{Bu}$ amaçla tasarım ve yapım aşamalarında yenilenebilir ve sürdürülebilir sistemler kurulmasına önem verilmektedir.

Ulaşım: Ulaşımla ilgili yapılan akıllı sistemler diğer akıllı sistemlerin içinde en eski olanlardan biridir. 1960'larda ilk olarak elektronik değişken mesaj işaretleri ve kırmızı ışık kameraları uygulamasıyla başlayan süreçte, insan-araç-altyapı-merkez arasında çok yönlü veri alışverişi, trafiğin güvenliği, yolların kapasitelerine uygun olarak kullanımı, mobilitenin arttırılması, enerji verimliliği sağlanarak çevreye verilen zararın azaltılması gibi amaçlarla tasarlanan çoklu entegre sistemleri ulaşım akıllı sistemlerinin konularındandır (UDH, 2014: 12). Bu alanda yapılan projeler bina ve çevresini ilgilendiren alanlardaki toplu taşıma, otopark, sosyal alanlar, yürüyüş ve bisiklet yolu gibi kullanım imkânlarını ele almaktadır. Sinyalizasyon sistemleri ve farklı ulaşım araçları için geliştirilen alternatifler bu tasarımlardan sadece bazılarıdır. Bunun yanı sıra, çok sayıda aracın kolaylıkla park etmesini sağlayacak sistemler, nefes alan yaşam alanları yaratırken oturma, gezme, yürüyüş alanlarında kullanılacak alt yapı sistemleri, 1sı, 1şık, hijyen, ses sistemleriyle kaliteli alanlar gibi birçok farklı konuyu da kapsamaktadır.

Yönetim: Standart bir binada bile esas işlev, binada kullanılan donanım, alan ve sistemlerin düzgün çalışmasıdır. Bu nedenle binanın işletme, kontrol, bakım gibi süreçlerinin de çok iyi tasarlanmış olması gerekir. Bu bağlamda binanın fiziksel, işlevsel ve güvenlik durumu önceliklidir. Akıllı sistemlerdeki en önemli fonksiyonların başında yönetim gelmektedir. Çünkü sistemlerin birbiriyle entegre edilmesi yeterli değildir. Aynı zamanda bu sistemi kullanabilecek, müdahale edebilecek ve yönetebilecek alana ihtiyaç duyulmaktadır. Yönetim aslında sistemin devamlılığ 1 ve çalışabilirliği açısından ayrıca önem taşımaktadır.

Su: Küresel sorunlardan biri haline gelen su tüketimi akıllı sistem tasarımında ele alınan önemli konulardan biridir. Etkin su yönetimi, su tasarrufu sağlamakla birlikte enerji verimliliğine ve zamandan tasarrufa da katkı sağlamaktadır. Birleşmiş Milletler Çevre Programına göre; dünyada 1400 milyon km3 su bulunmakta ancak rahat erişim sağlanabilen ve kullanım imkânı olan su oranı \% 0,4tür (Topçu, 2018). Bu düşündürücü değer ve farklı istatistikler akıllı bina sistemlerinde su maliyet verimliliğinin önemini vurgulamaktadır. Akıllı sistemlerde suyun etkin kullanımı, su tüketimi, sızıntıların önlenmesi ve suyun geri dönüşümü gibi birçok açıdan alternatif çözüm üretebilmektedir.

Atık: Su kadar önemli olan konulardan biri de atıklardır. Atıklar, endüstriyel, tehlikeli, inşaa, tarımsal, evsel, elektronik ve evrensel olarak tanımlanabilir (Vaughn, 2009:59). Atık yönetiminde evsel, tehlikeli ya da tehlikesiz atıkların azalması ve bir kaynakta toplanması, atıkların taşınması ya da geri kazanımı için yapılan çalışmalar akıllı sistemlerin alanlarındandır.

Kirlilik: Özellikle ozon tabakasındaki delinmeyle birlikte çevreye büyük zararları olan çevre kirliliğinin önlenmesi amacıyla bina ve çevresindeki su taşkını riski, azot salınımı, aydınlatmalar ve gürültü kirliliği gibi konular ele alınmaktadır.

Arazi kullanımı: Ekolojik değerler başta olmak üzere insan ve çevresi için uygun olması gerektiğinden bina ve çevresinin bulunduğu arazinin seçimi, ekolojik dengeye katkı sağlaması için ihtiyaç duyulan koşulların sağlanması için yapılan çalışmalardır.

Görüldüğü gibi, sözü geçen fonksiyonlar akıllı sistemlerin entegre edilmesi, dışarıdan kontrol edilebilmesi ve geliştirilebilir olması sayesinde birey ve toplum açısından fayda sağlayan sonuçlar elde edilmesini sağlamaktadır. Tek bir konut için tasarlandığında sadece o konut alanındaki yaşam kalitesini artırırken büyük site, mahalle ya da kent tasarımlarında etki alanı da aynı biçimde genişlemektedir. Özellikle büyük kentlerin sorunları 
olan ulaşım, trafik, otopark, yeşil alan düzenlemesi, rekreasyon alanları, elektrik ve su alt yapısı gibi konularda sorunların en aza indirgemesini bu yapılanma sayesinde mümkün olmaktadir.

\subsection{Akıllı Kent Tasarımı}

Akıllı kentler, akıllı binaların alt yapısıyla birlikte diğer yaşam alanlarının da akıllı sistemlerle donatılması anlamına gelmektedir. Akıllı kentler, akıllı sistemlerle donatılmış teknoloji demeti (harnessing technology) ya da sürekli geliştirilebilen ve ihtiyaçlar doğrultusunda yeniliğe açık olan çoklu teknolojiler olarak tanımlanabilir.

Akıllı kent kavramı, bilgi toplumunun dijital kentlere geçişinde ortaya çıkmıştır. Akıllı kentler, bilgi teknolojileriyle yaşamı ve işleyişi iyileştirmek için tasarlanırlar. Kısaca zeki, kentlerde öğrenmeyi, teknolojik gelişmeyi ve yeniliği destekleme yeteneğini ifade etmektedir. Bu bağlamda, her dijital şehrin akıllı olmadığını, ancak her akıllı şehrin dijital bileşenlerinin olduğunu söyleyebiliriz ( Komninos, Pallot \& Schaffers; 2013). Bugün, çoğu kaynak (dünya çapında) kentlerde tüketilmekte, ekonomik katkıda bulunmakta, aynı zamanda zayıf çevresel performanslarına da katkıda bulunmaktadır. Bu bağlamda kentler, dünya çapındaki enerjinin \%60- 80'ini tüketmekte ve GHG (Sera Gazı) emisyonlarından da büyük oranlarda sorumlu olmaktadırlar (Albino, Berardi \& Dangelico; 2015). Akıllı kentlerde enerji konusunda alınacak tedbirler, GHG ve hava emisyonlarını azaltmak, maliyetleri azaltmak ve süreçleri iyileştirmek gibi unsurlardır. Bununla birlikte, kentsel alan yoğunluğunun azalmasıyla, kişi başına düşen $\mathrm{CO} 2$ emisyonlarının kentsel alan yoğunluğunun artmasıyla birlikte düşmesi, elektrik ve ulaşım için daha fazla enerji tüketilmesine neden olmaktadır (Hammer vd., 2011). Dolayısıyla bugünkü kentler, ulaşım bağlantılarını, karma arazi kullanımlarını ve ekonomiye uzun vadeli olumlu etkileri olan yüksek kaliteli kentsel hizmetleri sağlayan çözümler aramaya başlamış ve buradan hareketle akıllı kentlerin önemi ortaya çıkmıştır. Bu aşamada temiz yakıt kaynaklarına geçiş için geliştirilen sistemler akıllı yapılar için önemli bir yer tutmaktadır. Motor, jeneratör, HVAC (Isıtma, Havalandırma, Klima), basınçlı hava sistemi, aydınlatma gibi enerji kullanımlı makine ve sistemler, akıllı kent projeleri için önemlidir.

Enerji tasarrufu kadar bir şehrin temizliği ve yaşanabilir bir yer olması da akıllı kent tasarımlarıyla geliştirilebilmektedir. Bir şehrin faaliyetlerinin akıllı olması akıllı kent kavramının gelişmesini sağlamaktadır (Giffinger, vd. 2007). Bunların bir kısmı yine enerji verimliliği ile sağlanırken bir kısmı da akıllı ulaşım sistemleri, üretimde kullanılan teknolojiler sayesinde olmaktadır. Hava kirliliğinin azaltılması, yeşil alanların artışı bir şehrin üretim, enerji, ulaşım sistemleri ve şehir planlamasıyla mümkün olmaktadır.

İlk akıllı kent ampirik çalışması olarak nitelendirilen Neirotti vd. (2016) çalışmasında elde edilen sonuçlar literatür açısından değerlendirildiğinde üç önemli konuya vurgu yapmaktadır. Öncelikle ekonomik gelişme ve kentin yapısal değişkenleri şehrin dijitalleşme yollarının tasarımında önemlidir. Bu nedenle özellikle baskın bir tasarım formatı yoktur. Ayrıca bölge ve şehrin yapısına göre akıllı kent müdahaleleri farklılık gösterebilmektedir. Bunlarla birlikte şehrin sosyal sermayesi, entelektüel sermayesi, kültürel yapısı, girişimcilik ve inovasyon gibi unsurlar akıllı kent tasarımlarında etkili olabilmektedir.

Akıllı kentler, toplumun tüm sektörlerinde birçok akıllı çözümün sonucunda ortaya çıkan alternatif bir çözüm olarak değerlendirilmektedir. Bu çoklu yaklaşımı aşağıdaki gibi özetlenebilir (Deloitte, 2015: 15): 

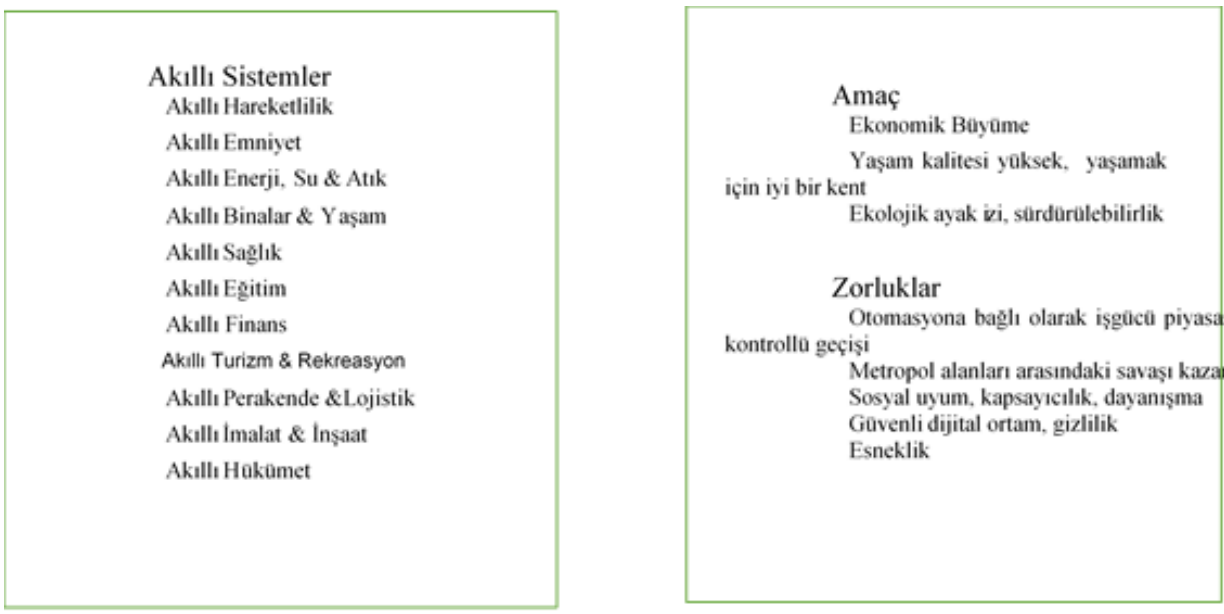

Şekil2. Ak1llı sistemlerin gelişim süreci

Kaynak: Deloitte Report (2015). Smart Cities. How rapid advances in technology are reshaping our economy and society.

Akıllı kentler, akıllıca bir akıllı kent yaratılacağına körü körüne inanmak değildir. Buradaki gerçekçilik beşeri sermaye tarafından başlayan bir ilerleme olduğunu görmektir. Çünkü akıllı kentler; akıllı yönetişim, dil, kültür, eğitime ihtiyaç duyar. Çünkü akıllı insan faktörü, yaşam boyu öğrenmeye olan yakınlık, sosyal ve etnik çoğulluk, esneklik, yaratıcılık, kozmopolitanizm, açı fikirlilik ve kamusal hayata katılım gibi çeşitli farklı yönlere sahiptir (Nam and Pardo, 2011).

Türkiye açısından değerlendirdiğimizde ise sözü geçen (Breem, Leed vd.) kriterlere ek olarak deprem ve çevresel sürdürülebilirlik üzerinde durulması gerekmektedir. Akıllı ev sistemleri, akıllı ulaşım sistemleri, akıllı şehir sinyalizasyon sistemi gibi konularda yeterli teknoloji, donanım ve eğitimli çalışanın olduğu görülmektedir. ABD'de (1969) ERGS (Elektronik Güzergâh Kılavuzluk Sistemi), Japonya'da (1973) CACS (Kapsamlı Araç Trafiği Kontrol Sistemi) gibi oluşumlar geliştirilse de ekonomik olmamaları nedeniyle sürdürülebilir olmamıştır. 1980'lere kadar hız tespit radarları, konuşa işaretler, plaka okuma sistemleri geliştirilmiş ve bugünkü AUS standartları (Akıllı Ulaşım Standartları) seviyesine gelinmiştir. Bu teknolojilerin hepsi Türkiye'de de kullanılmaktadır (UDH, 2016: 12-14). TBV (Türkiye Bilişim vakfi) (2016) çalışmasına katılan 25 büyükşehirden elde edilen rapora göre, büyükşehir belediyeleri, devlet ve özel işletmelerin işbirliğiyle çeşitli akıllı şehir uygulamaları kullanılmakta ancak yeterli olmamaktadır. Bununla birlikte gelecekte daha iyi amaca uygun çalışmaların yapılabileceği de vurgulanmaktadır (TBV, 2016).

Özellikle Türkiye'deki nüfus yoğunluğu ve nüfus artışı nedeniyle şehir yaşamında akıllı ulaşım sistemleri bir ihtiyaç haline gelmiştir. Akıllı sistemlerin kullanılmasına karşın bina ve konut yapımıyla ilgili Türkiye’ye özgü bir sertifikasyon sistemi bulunmamaktadır. Akıllı kent tasarımlarında Kepezaltı-Santral gibi büyük projelerin de olduğunu söylemek mümkündür (Kentsel Dönüşüm, 2017). Bununla birlikte akıllı bina yapılan alanlarda da dünyada en yaygın hale gelen BREEM ve LEED metotlarının uygulandığını söylemek mümkündür. Metropol yaşamda ihtiyaçların daha ön planda olması nedeniyle akıllı bina uygulamaları da ilk olarak büyük şehirlerdedir. İstanbul'da Akasya Acıbadem, Akbatı konutları, Özyeğin Üniversitesi Kampüsü, Nida Kule Göztepe ve Özdilek Levent ofis binası bu sertifikalarla değerlendirilen binalardandır. 
2013 sonunda dünyada yaklaşık 143 adet devam eden veya tamamlanmış akıllı kent projesi varken bu sayının giderek artması önemli bir göstergedir. 1900'lü yıllar itibariyle Amerika'da başlayan projeler daha sonra Kanada ve Avrupa'daki birçok ülkede ve Asya ülkelerinde yaygınlık kazanmıştır. Bugün ise dünyanın her yerinde yaşamı kolaylaştıracak akıllı sitemlerin tasarlandığını görmek mümkündür. Örneğin, Singapur, Tayvan ve Hong Kong gibi Asya ülkeleri, akıllı kent programları tasarlayarak ekonomik büyümeyi teşvik edecek bir yaklaşım izlemektedir. Singapur'un IT2000 planı, bilgi teknolojisini iş, yaşam ve oyuna dönüştüren "akıllı bir ada" tasarlanmışken, Tayvan'daki Taoyuan, E-Taoyuan ve UTaoyuan gibi hükümet işbirliğiyle yapılan projelerin, e-yönetişim ve yaşam kalitesini iyileştirerek sosyoekonomik katkı sağlamak amacıyla tasarlandığı görülmektedir (Albino, Berardi \& Dangelico; 2015). Akıllı şehir modeli olarak İstanbul Büyükşehir Belediye'sinin yaptığı çalışmalar, diğer ülkelerdeki çalışmalar kadar önemlidir. 2015 itibariyle akıllı şehir yaşam laboratuvarı, uluslararası fuar ve faaliyetlere katılım, akıllı şehir ulaşım hizmetlerinin hızlandırılması gibi projeler başlatılmıştır. İSBAK (İstanbul Bilişim ve Akıllı Kent Teknolojileri A.Ş) bünyesinde yürütülen proje ve AR-GE çalışmaları faaliyet alanlarını genişletmektedir (İSBAK, 2019).

Dünyadaki akıllı kentlerle ilgili hazırlanan proje sayısı yıllar doğrultusunda sürekli artmaktadır. Projeler ihtiyaçlar doğrultusunda geliştirilmekle birlikte çoğu projenin ortak çerçevesi olduğunu söylemek de mümkündür. Bu bağlamda bir projenin genel hatlarını aşağıdaki gibi gösterebiliriz.

Tablo 2. Akıllı Kent proje eylemleri

\begin{tabular}{|c|c|}
\hline \multirow{4}{*}{ 焉 } & Katılım \\
\hline & Şeffaflık ve bilgi erişilebilirliği \\
\hline & Kamu ve sosyal hizmetler \\
\hline & Çok seviyeli yönetişim \\
\hline \multirow{5}{*}{ 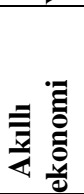 } & İnovasyon \\
\hline & Girişimcilik \\
\hline & Yerel ve küresel birbirine bağl1lık \\
\hline & Verimlilik \\
\hline & İşgücü piyasasının esnekliği \\
\hline \multirow{7}{*}{ 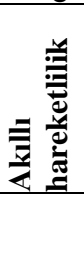 } & Trafik Yönetimi \\
\hline & Toplu taşıma \\
\hline & BİT altyap1s1 \\
\hline & Lojistik \\
\hline & Ulaşılabilirlik \\
\hline & Temiz, motorsuz seçenekler \\
\hline & Çok modelli \\
\hline
\end{tabular}

\begin{tabular}{|c|c|}
\hline \multirow{5}{*}{ 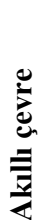 } & Ăg ve çevresel izleme \\
\hline & Enerji verimliliği \\
\hline & $\begin{array}{l}\text { Kent planlama ve kentsel } \\
\text { yenileme }\end{array}$ \\
\hline & Kaynakların yönetimi \\
\hline & Çevresel koruma \\
\hline \multirow{5}{*}{ 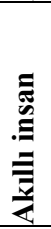 } & Dijital eğitim \\
\hline & Yaratıcılık \\
\hline & BİT etkin çalışma \\
\hline & $\begin{array}{ll}\text { Topluluk oluşturma } & \text { ve } \\
\text { kentsel yaşam yönetimi } & \end{array}$ \\
\hline & Kapsayıc1 toplum \\
\hline \multirow{6}{*}{ 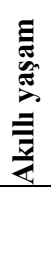 } & Turizm \\
\hline & Kültür ve rekreasyon \\
\hline & Sağlık hizmeti \\
\hline & Teknoloji ulaşılabilirliği \\
\hline & Güvenlik \\
\hline & $\begin{array}{l}\text { Sosyal yardım ve sosyal } \\
\text { içerme }\end{array}$ \\
\hline
\end{tabular}

Kaynak: Monzon, A. (2015). Smart Cities Concept and Challenges: Bases for the Assessment of Smart City Projects. Springer International Publishing, M. Helfert et al. (Eds.), CCIS. 579, s. 26. 
Yukarıda da görüldüğü gibi, akıllı kent projelerinin farklı aşamaları bulunmaktadır. Akıllı yönetişim öncülüğünde projelerde sosyoekonomik ve teknolojik konular farklı gruplar içinde ele alınmaktadır. Bu gruplardaki her konu hem akıllı sistemlerin oluşturulmasında hem de sürdürülebilirlik açısından değerlendirilmektedir. Kurulan yaşam alanlarının ya da kentsel dönüşüm gibi bir konutun yeniden inşa edilmesi sırasında ihtiyaçlar doğrultusunda sistem tasarımı yapılmakta daha sonra bilişim alt yapısıyla sistemler birbiriyle ilişkilendirilmektedir. Bir kontrol merkezinden izlenmekte ve müdahale edilebilmekte olan bu sistemlerde aynı zamanda kendi kendini kontrol edebilmesi de mümkün olabilmektedir. Yapay zekâ destekli sistemlerde ise kendi kendine karar veren mekanizmalar sayesinde olası sorunların önüne geçilmiş olmaktadır.

\section{Akıllı Sitemlerde Öğrenci ve Araştırmacıların İlgi Alanlarının Araştırılması: Uluslararası Öğrenci Kongresi Bildirileri}

Çalışmanın bu kısmında yükseköğrenim ve sonrasında akıllı kentlerle ilgili çalışmalardan örnekler verilmesi amaçlanmıştır. Küresel boyutta tüm çalışmalara ulaşmak ve burada irdelemek mümkün olmadığından İstanbul Maltepe Üniversitesi Uluslararası Öğrenci Kongresi MUISC'de (2018) bildirisi kabul edilen lisans, yüksek lisans ve doktora öğrencilerinin çalışmaları incelenmiştir.

\subsection{Yöntem}

$\mathrm{Bu}$ çalışmada nitel araştırma yöntemleri kullanılarak yargısal ölçme yapılmıştır. Bunun için 14-16 Mart 2018'de Maltepe Üniversitesi MUISC 2018 öğrenci kongresinde sunulan bildiriler örneklem olarak seçilmiştir. Kongrede akıllı sistemlerle ilgili 20 bildiri sunulmuştur. Bunlardan 10 tanesi akıllı kentler konusuyla ve akıllı sistemlerle ilişkili olduğundan araştırma grubunda 10 tane bildiri bulunmaktadır. Veri toplama aracı olarak, çalışmanın konusuyla ilgili bildiri tam metinleri üzerinden doküman incelemesi yapılmıştır. Doküman analizi, "mevcut kayıt ya da belgelerin, veri kaynăğ olarak, sistemli incelenmesi" (Best, 1959: 118 ) olarak tanımlanabilir. Dokümanların analizinde temel araştırma sorusu lisansüstü araştırmalar içinde akıllı kent ve sistemlerle ilgili hangi konular öne çıkmaktadır şeklinde tanımlanmıştır.

\subsection{Bulgular}

$\mathrm{Bu}$ çalışmada, veri toplamada kullanılan dokümanlar analiz edilmiş ve betimsel analiz yapılmaya karar verilmiştir. Betimsel analiz yöntemleri arasında farklı düşünceler bulunmaktadır. Bu çalışmada Walcott (1994) tarafından belirtilen analiz tekniği kullanılmıştır. Walcot'a göre, nitel bir araştırmada olaylar, veriler, bir öykü anlatıcısı gibi belirli bir düzen içinde aktarılır ve incelenen olayın dolaysız olarak aktarılmasına özen gösterilir. $\mathrm{Bu}$ bağlamda uluslararası öğrenci kongresinde sunulan bildirilerin sınıflandırılması ve analizleri aşağıdaki gibidir:

Öğrenci kongresinin ana teması 21. Yüzyılda küreselleşme ve sorunlar olarak belirlenmiştir. Bu başlık altında ENSAD mühendislik ve mimarlık bölümü öğrencileri akıllı sistemler/pasif tasarım konusu üzerine ağırlık vermeye karar vermiştir. Bu bağlamda gönderilen bildirilerden en nitelikli ve akademik değer içeren çalışmalar kongre sürecinde sunulmuştur.

Kongrede “keynote speaker”ların üzerinde durduğu temel konu akıllı sistemler, teknoloji, gelişmiş düzenekler ve akıllı kent, akıllı bina gibi kullanım yerleri olmuştur. Gelecek trendler ve gelecekte dünyanın temel ihtiyacının hızlı nüfus artışıla birlikte yaşam alanlarının yetersiz kalacağı altı çizilen en önemli konular olmuştur. Çalışmanın da temel 
araştırma konusu olan akıllı bina, akıllı kent konusundaki bildiriler ve konuları aşağıdaki gibi açıklanabilir:

Tablo 3. Öğrenci Kongresi Bildiri Alan ve Konuları

\begin{tabular}{lll}
\hline Akıllı sistemleri & Aquponic, Mühendislik alanındaki teknoloji gelişimleri & Türkiye \\
\hline Akıllı sistemler & İklim-Enerji tasarrufu & Portekiz \\
\hline Akıllı sistemler & Cihaz verimliliği & Yunanistan \\
\hline Akıllı sistemler & IOT, Üretici-tüketici ilişki ağı kurulması & Türkiye \\
\hline Akıllı sistemler & Yapay zekâ, sinir ağları & Ürdün \\
\hline Akıllı sistemler & Donanım/araç verimliliği & Türkiye \\
\hline Akıllı sistemler & Üretim verimliliği & Endonezya \\
\hline Pasif sistemler & Tasarruflu ev tasarımı & Filipinler \\
\hline Pasif sistemler & KASTİLYO tasarım önerisi & Filipinler \\
\hline Akıllı sistemler & Çevre-ekoloji dengesinin korunması için sistemler & Türkiye \\
\hline
\end{tabular}
gibidir:

Öğrenci kongresindeki çalışmaların konulara göre ağırlık istatistiği aşağıdaki

Tablo 4. Kongredeki akıllı sistem ilgi alanlarının ağırlıklı yüzdeleri

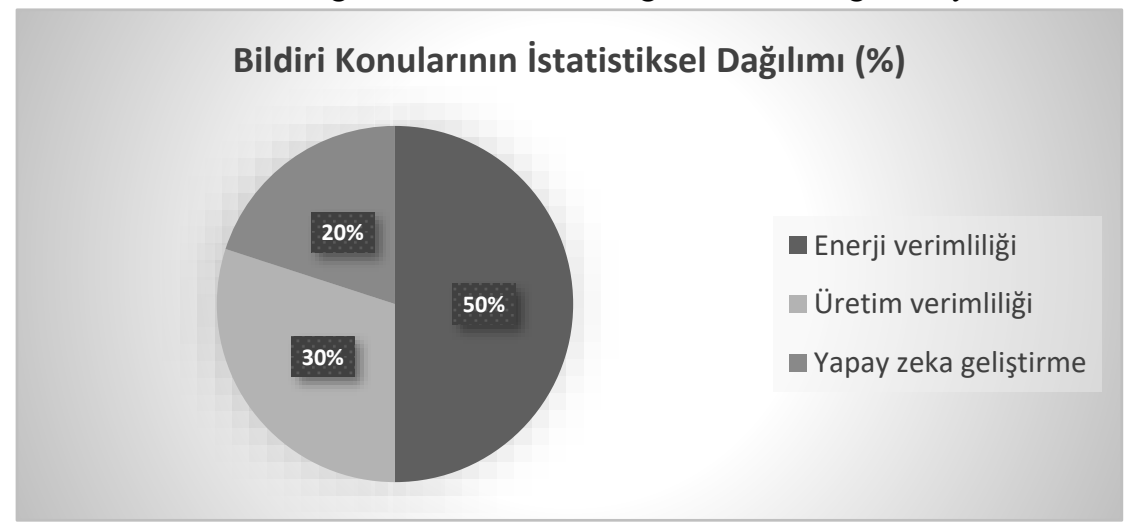

Çalışmalardan biri Aquaponic sistemlerini ele almıştır. Akıllı ev ve yeni bilişim teknolojilerinden biri olarak Aquaponic sistemin bugünkü popülerliği vurgulanmıştır. Karaca \& Dündar (2018) özellikle hobi bahçesinde kullanılabilecek çiftçilik teknolojisi olan sistemin, su ürünleri yetiştiriciliği için de tasarladıkları çalışmada, kullanılabileceğini belirtmektedir. Sistemi kullananlar yetiştirme alanındaki tüm verileri bilgisayara bu sistem aracılığıyla aktarabildikleri için yetiştirilen canlılar için gerekli olan her değişkeni değiştirebileceği tespit edilmiştir. Bu çalışmada hem akıllı bir sistemin geliştirilmesi hem de mevcut sistemlerin başka alanlarda da kullanılabileceği gösterilmiştir.

Akıllı sistemlerin geliştirilme ihtiyaçlarından biri enerji tüketimindeki artıştır. Bu nedenle bu alanda yapılan çalışmaların ayrıca önemli olduğunu söyleyebiliriz. Kongrede 2030 iklim-enerji paketini ele alarak enerji tasarrufu fikri sunan bir çalışma yapılmıştır. "2030 iklim-enerji paketi çok iddial olarak, enerji bileşiminde yenile bilirin payını \%27 olarak, \%27 enerji tasarruflu iyileştirmeleri ve 1990 yılına kıyas ile sera gazı emisyonunun \%40 azalmasını hedeflemektedir" (Savchuk, 2018). Bu çalışmada, enerji tüketiminin azaltılmasına yönelik çalışmaların kalkınma politikaları kapsamında nasıl ele alındığı da tartışılmıştır. Enerji piyasasının liberalleşmesi, siber güvenlik tehlikeleri gibi gelecek sorunlarının tespiti ile şimdiden önlem alınması gereken konular üzerinde de analizler yapılmıştır. Tespit edilen ve çıkarımda bulunulan sonuç, yapay zekâ yaklaşımları olmuştur. 
Enerji tasarrufu, iş verimliliği, zaman verimliliği ve insan memnuniyeti amaçlarıyla geliştirilen akıllı sistemler bazen farklı sistemleri birbirine entegre etmek yoluyla gerçekleştirilirken bazen de kullanılan makine, cihaz ya da donanımların verimliliğini artırma yoluyla gerçekleştirilebilmektedir. Bu konuya örnek çalışmalardan birinde biyoreaktör tasarımı önerisi sunulmuştur. Biyoreaktörler biyolojik ve/veya biyokimyasal süreçlerin kontrollü ortamlarda ve operasyonlarda farklı unsurların $(\mathrm{pH}$, sıcaklık, basınç, besi ve atık ortamı vb.) gerçekleştirilmesi için kullanılan cihazlardır. Bu cihazlar tasarlanırken, gaz safhası dağılımı, mikroorganizmaların asılımı ve sıvı safhasındaki ısı artışı gibi konulara dikkat edilmesi gerekmektedir. Pavlidis (2018)'e göre son on yıldır laboratuvarlarında yaptıkları çalışmalar ince gözenekli metal gaz püskürtme aletiyle donatılmış kabarcık sütunlar üzerinedir ve tasarım denklemlerinin geliştirilmesi aşamasına kadar ilerleme kaydedilmiştir. Bu çalışmada öne çıkan düşünce, düşük işletim maliyetleri ve yüksek enerji verimliliğinin sağlayacağı avantajlardır. Akıllı kent sistemleriyle direkt bir ilgisi olmasa da makine ve biyokimyasal süreçlerin kontrolünde verimlilik artışı sağlayabilecek sistemlerin benzerlerini kent sistemlerinde kullanılan makine ve teçhizatlarda da uygulamanın mümkün olabileceği sonucuna ulaşmak mümkündür.

Başka bir çalışmada, yeni cihaz, donanım tasarımı yapılmasının yanı sıra günlük sıklıkla kullanılan ürünlerle ilgili IOT ürünleri olarak nitelendirilen yeni bir ürün kategorisi ele alınmıştır. Çoşkun (2018) bugünkü teknolojilerin kullanımında emniyet, gizlilik ve güvenlik konularının önemini vurgulamaktadır. Özellikle karşılıklı ortak kullanım ve kaynak paylaşımında güvenliğin giderek önemli hale geldiği belirtilmektedir. Bu bağlamda iletişim ağları anlamına gelen bu ürünleri, mevcut teknolojik ürünlerden ayıran özellikleri ise veri toplama, işleme gibi detaylarla kullanıcı ve üreticilerin sürekli iletişim halinde olmalarıdır. IOT teknolojisinin mevcut günlük kullanılan ürünlere entegre edilmesinin farklı verimlilikler sağlayabileceği üzerinde durulmuştur.

Cihazlar, araçlar ve akıllı sistemlerin ortaya çıkması için sıklıkla başvurulan alanlar vardır. Bunlardan biri yapay zekâ ve mühendislik bileşimidir. Bu konuyu ele alan çalışmada akıllı sistemlerin önemi üzerinde durduktan sonra üç temel noktaya vurgu yapılmıştır (yapay zekâ, jeoteknik mühendisliği ve iş zekâsı). Zeki sistemler ve bilgisayar tabanlı akıllı sistemler birlikte kullanılabilmektedir. Sözü geçen üç unsur bir arada çalışabilmektedir (Daraghmeh, 2018). Bu bağlamda bu çalışmada, jeoteknik mühendisliğinde yapay sinir ağları kullanılarak yapılan uygulamalar incelenmiş ve tartışılmıştır. Özetle, akıllı sistemlerin farklı form ve alansal gelişimleri üzerinde yazın, alan taraması yapılmıştır.

Benzer başka bir çalışmada da sanayi sektöründe kullanılan Waelz fırının tükettiği enerjinin azaltılması için bir otomasyon sistemi tasarlamanın mümkün olduğunu vurgulanmıştır. Öncelikle sanayi sektöründe enerji tüketiminin yüksek olduğu uygulamalarda enerji verimliliğinin ülke ekonomisine katkısı yüksek olmaktadır (Ateş \& Rusen, 2018). Bu sayede hem ideal yanma verimliliği hem de enerji verimliliği sağlanmış olacaktır. Fırın kullanımının yüksek olduğu üretim alanlarında enerji tasarrufu ve genel firma performansı özellikle gelecek tehditlerinin azaltılması açısından önemlidir.

Sözü geçen iki çalışmayı ve diğer çalışmaları da destekleyen bir başka çalışmada ise, sürdürülebilir kalkınma perspektifinde doğaya uygun ürünlerle ilgili atık yönetimi konuları ve çevresel yaklaşımlar değerlendirilmiş ve alandaki yeniliklerin önemi vurgulanmıştır. Yalın üretim araçlarının kullanılması hem ürün teslim süresini kısaltmakta hem de atık oluşumunu önlemektedir (Ariyani, 2018). Bu çalışma diğerlerine göre kavramları, kalkınma konusunu, enerji tasarrufunu ve atık yönetimi konuları daha genel olarak bir çerçeve altında sunmuştur. Çalışmanın önemli olan kısmı, konuları bir araya toplayan derleme çalışması olmasıdır. 
İnsan yaşamının büyük oranda geçirildiği mekânlar olan binaların, insan vücuduna somut, soyut etkileri oldukça çoktur. Bununla birlikte binaların çevresel etkileri ve bu çevresel etkilerin dolaylı olarak insandaki etkileri de birleştirilince bina tasarımlarının önemi ortaya çıkmaktadır. Genel olarak akıllı bina ve akıllı kent projelerine fikir verebilecek nitelikte olan bu çalışma, aynı zamanda tüketicinin bilinçlenmesi açısından da bilgi aktarıcı olmuştur. Bu konuda yapılan çalışmalardan biri tasarruflu ev tasarımıdır. Filipin için düşünülen bu proje de bölgenin coğrafi yapısı temel alınmıştır. Filipin'in tropik bir bölge olması nedeniyle kendi evini inşa etmek isteyenler birçok problemle karşılaşmaktadırlar. Ayrıca, mevcut ekonomik yetersizlik nedeniyle tercih edilen binaların düşük kaliteli binalar olduğu vurgulanmıştır (Trinidad; Basierto \& Geraldine, 2018). Bu çalışmada yapılan tespitler doğrultusunda basit ama rahat ve tasarruflu bir ev yapılması için akıllı sistemlerden nasıl faydalanılacağı üzerinde durulmuştur.

Benzer bir çalışmada yine Filipinler'deki ev, bina ve yaşam alanları üzerinde durulmuştur. $\mathrm{Bu}$ çalı̧̧mada Filipinler'de enerji tüketimini ve tropikal iklim etkilerini azaltarak doğal kaynakların korunmasını ön gören pasif bir sistem önerisi sunulmuştur. KASTILYO adı verilen pasif sistemle, soğutma ve ısıtma için yenilikçi çapraz havalandırmayı uygulayarak bina yapılabilmektedir. Bu sistemle yay sirkülasyonu ön plana çıkacak ve insanları taşıyan mekanik araçlar monte edilebilecektir. Bu yolla karbon ayak izi azalmış olacaktır (Montabon; Sandoval \& Togado, 2018). Bu çalışma, Filipinler ve Filipinler'den farklı coğrafik problemleri olan ülke ve kentler bağlamında yeni kentsel yerleşimin etkin ve verimli bir şeklini sunmuştur.

Akıllı bina sistemlerini destekleyen bir başka çalışmanın temel alanı da akıllı kent sistemleri olarak belirlenmiştir. Akıllı kent sistemleri için gereklilikleri, dünyada ve Türkiye'deki oluşumları, mevcut projelerde hangi özelliklerin öne çıktığını ve Türkiye'de yapılan akıllı sistemlerle ilgili uygulamaların araştıııldı̆̆ bir derleme çalışmasıdır. Çevresel zararları azaltmak amacıyla ürün, malzeme, süreç, enerji, üretim ve teknoloji gibi unsurların sürdürülebilirlik kapsamında birlikte değerlendirilmesinin önemli olduğu vurgulanmaktadır (Kutbay \& Yavuzcan, 2018). Mevcut yapılanmayı ve projeleri aktarması aynı zamanda ülkesel gelişim boyutunda hangi aşamada olduğumuzu göstermiştir. Ayrıca gelecek projeler için de fikir veren paylaşımları bulunmaktadır.

\section{Sonuç ve tartışma}

Akıllı binaların ve akıllı kentlerin sürdürülebilirlik anlamında sağlayacağı katkılar oldukça açıktır. Bunlar, 1sıtma, soğutma, elektrik, su, aydınlatma gibi enerji kullanımlarında ve yangın, doğal afet, güvenlik gibi enformasyon sistemlerinde maksimum verimlilik sağlayacak sistemlerin ve sistemler arası ilişki ağının kurulabilmesi avantajıyla sürdürülebilir katkılardır. Bu bağlamda makale, giderek daha popüler hale gelen bir kavramın (akıllı şehrin) anlamını açıklığa kavuşturmaya çalışmaktadır.

Bir kentin akıllı olarak nitelendirilmesi, şehirle ilgili sorunların ne şekilde ele alındığıyla bağlantılıdır (Neirotti vd.). Örneğin iyi bir şehir planlaması yapmak (Anthopoulos \& Vakali), daha iyi yönetişim sağlamak (Meijer \& Bolívar, 2016), trafik sorununu çözmek ya da yaşam alanlarını güzelleştirmek (Cohen, 2013) gibi hedeflerle tasarlanmaktadır. Bu nedenle akıllı sistemlerin ihtiyaçlar doğrultusunda ele alınıp tasarlanması çözüme ulaşmayı kolaylaştıracaktır.

Bununla birlikte kent yaşamını akıllı sistemlerle donatmak ve sürekli iyileştirmek oldukça zor ve bilgi, teknoloji gerektirmektedir. Özellikle nüfus artışılla birlikte sosyoekonomik gelişmeler devam ederken akıllı sistemlerin geliştirilmesi pozitif dışsallık elde edilmesi demektir. Dolayısıyla akıllı kentleşme aynı zamanda sürdürülebilir bir kentsel büyüme modelidir. Kentsel büyüme modellerinde en önemli olumsuzluklardan biri 
demografik değişimler ve finansal krizlerdir. Bu bağlamda kentsel gelişim planlarında uzun vadede elde edilecek sonuçlar için doğru planlama ve uygulamalara ihtiyaç vardır. Akıllı sistemlerin yer aldığ kriterleri açısından önemli olacaktır. Literatürde sözü geçen yeşil bina sertifikasyon sistemleri, binaların akıllı olma kriterlerini belirlemenin dışında sürdürülebilir ve kalkınma odaklı olmasını sağlamaktadır. Yapıların çevreye yaydığı olumsuz etkileri kontrol altında tutabilmek için yeşil bina sertifikaları olan binaların tasarlanması bir zorunluluk haline gelmiştir.

Akıllı kentlerin temel yapıtaşı akıllı binalardır. Akıllı bir kent kurabilmek için akıllı bina fonksiyonlarıyla donanmış binalar, kentin ışıklandırması, alt yapı sistemleri, arazi kullanımı, ulaşım imkânları, araçların park alanları, alış veriş merkezleri, iş yerleri, üretim alanları ve bunların atık yönetimi, enerji kaynakları gibi birçok etkenin bir yönetim merkezinden yönetilebiliyor olması anlamına gelmektedir. Gelecekte bu sistemlerin birbirine entegre edildiği yaşam alanlarına sahip olmak hayal değildir. Bugün kullanılan teknoloji ve geliştirilen sistemlerin gelecekte alternatif şehir sistemi olarak sunulması mümkündür.

Literatürde akıllı kent tasarımlarındaki hedefler genellikle güvenli toplum, temiz ve sürdürülebilir çevre, enerji tasarrufu, koruyucu, üretim verimliliği ve yapay zekâ uygulamalarıdır. Çalışmalar ise en çok enerji tasarrufu, üretim verimliliği ve akıllı ulaşım sistemlerini vurgulamaktadır. Kongrede tebliğ edilen çalışmalarda lisansüstü araştırmacıların teknoloji alt yapılı akıllı sistemleri takip ettiği, bu konularla ilgilendikleri ve katkıda bulunmaya çalıştıkları görülmektedir. İnovatif çalışmalar ve tasarımlar bu konuda hızlıca yol alınabileceğinin göstergesidir.

Geçmişten bugüne gerçekleştirilen akıllı kent sistemlerinin şehrin ihtiyaçları doğrultusunda farklılaştı̆̆ 1 görülmektedir. Bir ülkede kentsel gelişime odaklanırken başka bir ülkede akıllı ulaşım sistemlerine ağırlık verildiği görülmektedir. Öğrenci çalışmaları da değerlendirildiğinde kendi ülkeleri bağlamında üretim ya da enerji verimliliği üzerine yoğunlaştıkları görülmektedir. Örneğin Filipinler'de mimari tasarımda geliştirilen akıllı tasarımlar görülürken Türkiye'de üretim verimliliği sağlayacak tasarımların ağırlıkta olduğu anlaşılmaktadır. Bununla birlikte Türkiye'de özellikle büyükşehirler için geliştirilen akıllı ulaşım sistemleriyle ilgili bir çalışmayla karşılaşılmamıştır. Bu bağlamda öğrencilerin eğitim sürecinde ülke ihtiyaçlarının ve mevcut tasarımlarının takibi de mutlaka etken olmaktadır.

Kentsel gelişim projelerinde yerel yönetim, özel işletmeler ve STK'ların işbirliğiyle kentsel gelişim stratejilerinde akıllı kent ya da teknolojik kent projeleri tasarlamak o bölgenin yaşanılabilir yer seviyesini artıracaktır. Şu ana kadar yapılan tasarım ve gerçekleştirilen projeler doğrultusunda yenilerinin geliştirildiğini de görmekteyiz. Akıllı kent sisteminin akıllı bina, akıllı ulaşım, akıllı yönetişim, akıllı sistemler üzerinden tanımlanması beklentilere kolaylıkla ulaşılabileceği umudunu vermektedir. Sürdürülebilir kalkınma çalışmalarında özellikle yapılacaklar arasında yer alması gereken konulardan biri olmaktadır.

$\mathrm{Bu}$ değerlendirmeler doğrultusunda makalenin, küresel boyutta akıllı kentler konusunda çalışanlara, inşaat ve yapı sektörüne, kalkınma politikalarına, şehir planlama, mimar ve inşaat sektörüne katkı sağlayabileceği düşünülmüştür.

\section{Kaynakça}

Albino, V.; Berardi, U. \& Dangelico, R. M. (2015). Smart Cities: Definitions, Dimensions, Performance, and Initiatives. Journal of Urban Technology, 22(1), 3-21.

Anbarc1, M., Giran, Ö. \& Demir, İ.H. (2012). Uluslararası Yeşil Bina Sertifika Sistemleriyle

Türkiye'deki Bina Enerji Verimliliği Uygulaması. e-Journal of New World Sciences Academy, 7(1), 368-383. 
Anthopoulos, L. G., \& Vakali, A. (2012). Urban planning and smart cities: Interrelations and reciprocities. The Future Internet Assembly. 178-189.

Ariyani, D. (2018). The application of Lean Manufacturing method using Value Stream Mapping and Value Stream Analysis Tools to reduce waste in the production of Bags from "Agel". MUISC 2018 ENSAD International Student Congress presantation.

Ateş, M. \& Rusen, S. E. (2018). Boosting Burning Efficiency of Waelz Furnace. MUISC 2018 ENSAD International Student Congress presantation.

Bell, J., 2003. Is "smart" always "sustainable" in building design and construction?, Smart and Sustainable Built Environment, Brisbane, Australia, November, 1-6.

Clements, D. J. (1998). What Do We Mean By Intelligent Buildings. Term Project in The University of UK.

Cohen, B. (2013). The Smart City Whell. https://www.smart-circle.org/smartcity/blog/boydcohen-the-smart-city-wheel/ (Erişim tarihi: 02.01.2019).

Coşkun, M. S. (2018). The Integration of IOT Technology Into the Existing Consumer Products. MUISC 2018 ENSAD International Student Congress presantation.

Çevre Dostu Yeşil Binalar Derneği (2018). Sağlıklı Toplumlar, Yaşanabilir Bir Çevre. https://cedbik.org/ (Erişim tarihi: 18.09.2018).

Daraghmeh, S. (2018). The Rise of Smart Systems. MUISC 2018 ENSAD International Student Congress presantation.

Dirks, S.; Gurdgiev, C. \& Keeling,M. (2010). Smarter Cities for Smarter Growth: How Cities Can Optimize Their Systems for the Talent-Based Econom. Somers, NY: IBM Global Business Services.

Eger, J.M. (2009). Smart Growth, Smart Cities, and the Crisis at the Pump A Worldwide Phenomenon. I-Ways 32(1), 47-53.

Enerji ve Tabi Kaynaklar Bakanlığı Bilgi Merkezi (2018). İklim Değişikliği ve Uluslararası Müzakereler.

http://www.enerji.gov.tr/tr-TR/Sayfalar/Iklim-Degisikligi-ve-Uluslararasi-Muzakereler (Erişim tarihi: 26.07.2018).

Erdede, S. B.; Erdede, B. \&Bektaş,S. (2014). Sürdürülebilir Yeşil Binalar Ve Sertifika Sistemlerinin Değerlendirilmesi. 5. Uzaktan Algılama-Cbs Sempozyumu (UZALCBS 2014), 14-17 Ekim 2014, İstanbul.

Giffinger R., Fertner C., Kramar H., Kalasek R., Milanović N.P., Meijers E. (2007) Final Report: Smart cities Ranking of European medium-sized cities, Vienna, Centre of Regional Science (SRF), Vienna University of Technology.

Greenbang (2011). Eight Definitions of 'Smart Buildings'. https://sustainabletechnologyforum.com/from-inspired-to-awful-8-definitions-of smartbuildings_18078.html (Erişim tarihi: 09.07.2018).

Hammer, S.; Kamal-Chaoui, L.; Robert, A. \& Plouin, M. (2011). Cities and Green Growth: A Conceptual Framework, OECD Regional Development Working Papers 08, OECD Publishing.

Istrate, E.; Berube, A. \& Nadeau, C. A. (2011). Global MetroMonitor

https://www.brookings.edu/wp-content/uploads/2016/06/0118_global_metro_monitor.pdf (Erişism tarihi: 21.07.2018).

İSBAK (2019). İstanbul Bilişim ve Akıllı Kent Teknolojileri A.Ş http://isbak.istanbul/ (Erişim tarihi: 02.01.2019).

Karaca, M. A. \& Dündar, S. (2018). Smart Aquaponic System. MUISC 2018 ENSAD International Student Congress presantation. 
Karagöl, B. (2013). Bilgi ve İletişim Teknolojilerinin Enerji Verimliliğine Katkısı. Yayınlanmış Uzmanlık Tezi. Bilgi Toplumu Dairesi Başkanlığı. Yayın no: 2850, 38.

Kentsel Dönüşüm (2017). Ak1llı Kentsel Dönüşüm Projesi. http://www.akillikentler.org/kentsel-donusum/3096/2/akilli-kentsel-donusumprojesi-basliyor.html (Erişim tarihi: 29.12.2018).

Komninos, N., Pallot, M. \& Schaffers, H. (2013). Smart Cities and the Future Internet in Europe. Journal of the Knowledge Economy, 4(2), 119-134. doi: 10.1007/s13132012-0083-X

Kuhn, D., Ellis, K., Fies, B., Hannus, M. Oza, N., Pille, H., Stöckert, H. \& Tetri, E. (2011). Knowledge and Current Practice, Revisite Projesi, ICT4EE.

Kutbay, H. \& Yavuzcan Güçlü, H. (2018). Developing Environmental Solutions Trough Materials. MUISC 2018 ENSAD International Student Congress presantation.

Marsal-Llacuna, M. L.; Colomer-Llinàs, J. \& Meléndez-Frigola, J. (2014). Lessons in urban monitoring taken from sustainable and livable cities to better address the Smart Cities initiative, Technological Forecasting and Social Change, 90, 611-622.

Meijer, A., \& Bolívar, M. P. R. (2016). Governing the smart city: a review of the literature on smart urban governance. International Review of Administrative Sciences, 82(2): 392-408.

Montabon, İ. J.; Lan Sandoval, S. B. \& Togado, M. R. B. (2018). KASTILYO: Proposed Philippine Arcology Building. MUISC 2018 ENSAD International Student Congress presantation.

Mori, K. \& Christodoulou, A. (2012). Review of Sustainability Indices and Indicators: Towards a New City Sustainability Index (CSI), Environmental Impact Assessment Review 32(1), 94-106.

Monzon, A. (2015). Smart Cities Concept and Challenges: Bases for the Assessment of Smart City Projects. Springer International Publishing, M. Helfert et al. (Eds.), CCIS 579, 17-31,

Nam, T. \& Pardo, T.A. (2011). Conceptualizing Smart City with Dimensions of Technology, People, and Institutions. Proceedings 12th Annual International Digital Government Research Conference: Digital Government Innovation in Challenging Times, 282-291.

Neirotti, P., De Marco, A., Cagliano, A. C., Mangano, G., \& Scorrano, F. (2014). Current trends in Smart City initiatives: Some stylized facts. Cities 38: 25-36.

Ofoegbu, E. O. \& Ogunmakinde, O. E. (2014). A User Activity Based Intelligent Building Design for Full Automation of A One Bedroom Apartment Building. International Journal of Innovation and Scientific Research. 6(1), 82-91.

Özçuhadar, T. \& Öncel, P. (2017). Eko Tasarım. Sürdürülebilir Üretim ve Tüketim Yayınlar1- IV. https://recturkey.files.wordpress.com/2017/02/eko-tasarim.pdf (Erişim tarihi: 26.07.2018).

Pavlidis, T. (2018). On The Design of Biorectors Equipped with Fine Pore Sparger. MUISC 2018 ENSAD International Student Congress presantation.

Peluffo, M. (2015). Defining Today's Intelligent Building.

https://www.commscope.com/Blog/Defining-Todays-Intelligent-Building/

Saunders, T. (2008). A Discussion Document Comparing International Environmental Assessment Methods for Buildings.

http://www.breeam.com/filelibrary/International\%20Comparison\%20Document/Comparsio n_of_International_Environmental_Assessment_Methods01.pdf (Erişim tarihi: $2 \overline{6} .0 \overline{9} 2018)$. 
Savchuk, O. (2018). Application of Machine Learning for Energy Systems: A review. MUISC 2018 ENSAD International Student Congress presantation.

Serbini, K., Krawczyk, R. (2004). E-design in Architecture KFUMP. 1ST ASCAAD International Conference, Dhahran, Saudi Arabia.

Seydioğulları, H. S. (2013). Sürdürülebilir Kalkınma için Yenilenebilir Enerji. Planlama, 23(1), 19-25.

Sharples, S., Callaghan, V. \& Clarke, G. (1999). A Multi-Agent Architecture for Intelligent Building Sensing and Control, International Sensor Review Journal, 3.

TBV (2016). Akıllı Şehirler Değerlendirme Raporu. http://tbv.org.tr/Turkiye_Akilli_Sehirler_Degerlendirme_Raporu-Web.pdf (Erişim tarihi: 29.12.2018).

Trinidad, C. K. B.; Basierto, T. \& Geraldine, F. D. M. (2018). Balay-Hayahay: Philippine Passive House Design. MUISC 2018 ENSAD International Student Congress presantation.

Topçu, R. A. (2018). Su Yönetimi ve Enerji Verimliliği. Su kültürü makalesi.

https://www.temizmekan.com/su-yonetimi-ve-enerji-verimliligi/ (Erişim tarihi: 02.10.2018).

UDH (2014). Ulusal Akıllı Ulaşım Sistemleri Eylem Planı raporu. www.udhb.gov.tr (Erişim tarihi: 18.07.2018).

Ulaş, C. (2006). Akıllı Binaların Çevresel Sürdürülebilirlik Açısından Değerlendirilmesi. Ístanbul Teknik Üniversitesi, Fen Bilimleri Enstitüsü Yüksek Lisans Tezi.

Varınca, K. B. \& Gönüllü, M. T. (2006). Yenilenebilir enerji kaynaklarının kullanımının çevresel olumlu etkileri. VI. Ulusal Temiz Enerji Sempozyumu.

Walcot, H. F. (1994). Transforming Qualitative Data: Description, Analysis and Interpretation. London: SAGE Publications.

Winters, J.V. (2011). Why are Smart Cities Growing? Who Moves and Who Stays. Journal of Regional Science, 51(2), 253-270.

Zsebik, A. (2018). Smart/Intelligent Buildings. NOGATE Programme New ITS Project, Ad Hoc Expert Facility.

Zygiaris, S. (2013). Smart City Reference Model: Assisting Planners to Conceptualize the Building of Smart City Innovation Ecosystems. Journal of the Knowledge Economy 4(2), 217-231. 